\title{
Universal Maqāṣsid al-Sharī'ah and Their Modern Application: Towards Ensuring a Peaceful and Secured Environment
}

\author{
Mohammad Shihan \\ Department of Fiqh \& Usul Al-Fiqh, \\ International Islamic University Malaysia \\ zihanaj@gmail.com \\ Abdulhamid Mohamed Ali Zaroum \\ Assoc. Prof., Department of Fiqh \& Usul Al-Fiqh, \\ International Islamic University Malaysia \\ alzaroumi@iium.edu.my \\ Muhammad Amanullah \\ Professor, Department of Fiqh \& Usul Al-Fiqh, \\ International Islamic University Malaysia \\ amanullah@iium.edu.my
}

\begin{abstract}
The maqāșid theory is a popular trend in Islamic legal theories. Contemporary scholars view it as a valid method of interpreting the revealed text and as a valuable instrument for solving contemporary issues because it helps reform Islamic thought and civilization. Indeed, the idea of maqāșid al-Sharī ${ }^{\prime} a h$ has been widely studied and expanded by modern scholars of Islamic legal theory. Chiefly, Ibn 'Ashur and contemporary MaqÉsid scholars renewed the scholarly discourse and ensured its proliferation and wide acceptance in legal studies. It has emerged as a new science that connects with all other legal disciplines. Thus, scholars firmly assert that the maqāșid al-Sharī ${ }^{-} a h$ constitute the most important intellectual means and methodologies for Islamic reform today. Consequently, the researchers aim to examine the modern discourse of Maqāșid al-Sharí ${ }^{c} a h$ and the latest developments beyond the universal MaqÉÎid. Mainly, the researchers scrutinize the two objectives namely the preservation of the environment via the protection of life and wealth. Accordingly, this article follows the qualitative method of data collection and analysis. Among the findings of the research is that the latest developments of Maqāssid al-Sharī ${ }^{`} a h$, open the door of ijtihäd widely to create ample areas for jurists to regulate the affairs of the Muslim ummah. Further, the maqāssid al-Sharī'ah do not reflect only the objectives of Islamic law; their role goes beyond and is used to formulate basic principles and values related to global peace and human welfare. Hence, they have greatly contributed to the revival of Islamic thought and have opened a wider space for the application of Islamic law pertaining to peaceful environment.
\end{abstract}

\section{Introduction}




\section{Universal Maqūssid al-Sharī'ah and Their Modern Application: To-wards Ensuring a peaceful and Secured Environment}

The five necessities of human existence, best known as maqāșid alShari ${ }^{-} a h$ serve as a methodology of shaping the Muslim mind to address new challenges and problems, considering the time and space of the modern world. Accordingly, many contemporary scholars have proposed the maqūssid al-Sharī ${ }^{\circ} h$ as a new way of thinking and innovative methodology to solve novel and complex issues. More importantly to explore the universal objectives namely the protection of faith, life, reason, wealth, and progeny. Since Ibn Ashur, the latest developments in universal maqūsid al-Sharī ${ }^{\prime} a h$ opened the door of ijtihād to create ample areas for jurists to regulate the affairs of the Muslim ummah. Consequently, the legal scholars emphasize that the maqūssid al-Sharīah do not reflect only the objectives of Islamic law; their role goes beyond and is used to formulate basic principles and values related to human welfare. Further, the five universal and essential objectives are taken as a framework when deriving new rulings for partial matters. Hence, this article elucidates the role of the maqūsid al-Sharī ${ }^{\top} a h$ in the contemporary world. Thus, the researcher explored the universal objectives while primarily relying on the viewpoint of contemporary maqāssid scholars to meet the present-day requirements.

This article discusses the five higher objectives of Islamic law which are the preservation of faith, life, intellect, wealth, and progeny, and the modern emphasis on their developmental and promotional aspects. The last section of it suggests certain thematic extensions as proposed by modern maqāșid scholars.

\section{The universal objectives of the Sharīah}

The intellectual discourse on the higher objectives of the Sharī $a h$ has its beginnings in early Islamic legal theory. Hence, from Imam al-Juwayni in classic times to Raysuni, legal scholars have regularly contributed to this subject. Notably, modern scholars have enriched this subject with modern terminology and contributed to its recent development. The objectives of Islamic law have emerged as a conceptual framework for many scholarly disciplines other than philosophy and social sciences. These new developments in the study of universal maqāșid have greatly contributed to the revival of Islamic thought and have opened a wider space for the application of Islamic law. Accordingly, the classic objectives of the Sharī $a h$ are protection of faith, life, property, intellect, and progeny. Imam al-Qarafi 
Mohammad Shihan, Abdulhamid Mohamed Ali Zaroum, 468

Muhammad Amanullah

added the preservation of honor as the sixth objective. (Ibn Ashur, ed. 1997)

The legal scholars of have given these five basic objectives different names and they are known as al-kullīyāt al-kham, (Rysuni Ahmad, 2013) al-ușūl al-khamsah, (Rysusni Ahmad, 2013) kullīyāt al-sharī‘ah, maqūṣid al-'alīyah, al-maqāṣid al-kullīyah, (Attia Gamal, 2007) al-arkān al-khamsah, (Al Amiri Abu al-Hasan, ed. 1967 and Rysuni Ahmad 2013) and al-ḍarūrìyât al-khams. (Rysuni Ahmad, 2013). This is due to their importance and broader acceptance among all religions and all religious laws before Islam. Therefore, Imam al-Gazali said, "Preventing the loss of these five fundamentals and protecting them can never be neglected by any religious community or legal system meant for the good and wellbeing of humankind." (Abu Hamid al-Gazali, 1997: 417-422) These are common areas to cooperate with other religious communities and are regarded as fundamental human rights. Ibn Ashur asserts that realizing these five indispensable objectives is essential for the individual and the community at large. The smooth function of the social order depends on the preservation, protection, and promotion of these five essentials; without these, the public order will be collapsed. (Ibn Ashur, trans. 2006)

The argument forwarded by Rejeb Senturk's is more applicable to Muslim minorities living in non-Muslim environments. He relates the higher objectives of Islamic law to human inviolability and deliberates in terms of universal human rights. He explains that the classical Muslim jurists never claimed to be the fathers of universal human rights, but human inviolability ('ismah al-ädamiyinn) is accepted by all religions. He notes that this is a universal rule that constitutes the basis for all legal systems in history to date. Further, the axiomatic inviolability rights (kullīy $\bar{a} t)$ and universal human rights are based on the concept of the inviolability of human life, property, mind, religion, family, and honor (dignity). More importantly, these rules constitute the common ground between the Islamic legal system and other legal systems. (Rajeb Senturk, 2013) 
469 Universal Maqāṣid al-Sharī'ah and Their Modern Application: To-wards Ensuring a peaceful and Secured Environment

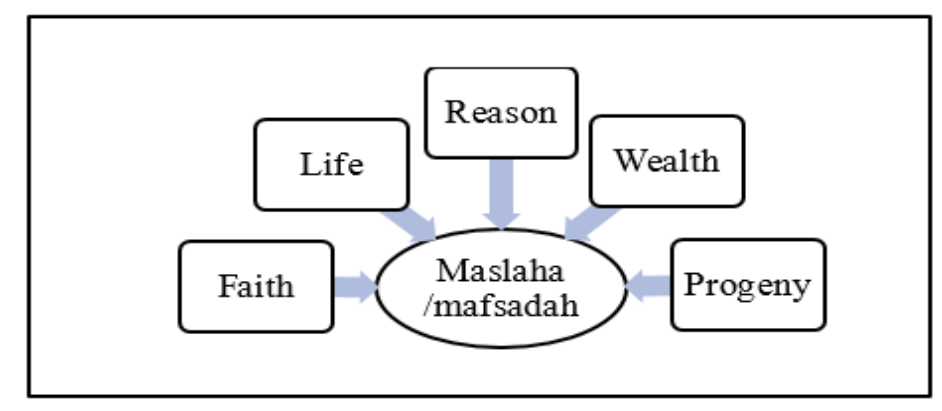

Throughout history, the subject of fundamental rights that are protected by the fundamental principles of Islamic law has earned the attention of many legal scholars and jurists. However, Abu al Hasan al- 'Amiri al-Faylasufi (d. 371AH) is known as the first scholar who laid the foundation for the theoretical classification of purposes of law based on prescribed criminal punishments ( $h u d \bar{u} d)$. (Al Amiri Abu al-Hasan, ed. 1967 and Rysuni Ahmad, 2013) In the same line, al-Tufi argued that the penalties secure the preservation of faith for those who violate religious teachings, the human faculty of reason is preserved by giving punishment for consuming intoxicants, the preservation of human life is ensured by providing an appropriate penalty, the preservation of progeny is ensured by the punishment of the unfaithful partner, and the preservation of wealth is secured by the punishment of the thief. (Zuhri Saifudin, 2019)

Finally, all these five essential needs are taken as a framework when deriving a ruling for partial matters. Therefore, Rysuni (2014) asserts that the maqāșid al-Sharī' $a h$ can be used as a framework when deriving a ruling for a partial issue. Hence, all five fundamental objectives (faith, life, wealth, reason, and progeny) have to be considered by the faqi $h$ who generates a ruling in a particular case. In short, whatever leads to harm should be prevented, and whatever leads to benefit should be promoted. This is set as a condition for independent reasoning. This approach was already taken by Imam al-Gazali who stated, "There are five objectives of Shari' ${ }^{\prime} a h$, namely the protection of faith, life, wealth, reason, and progeny. Hence, whatever leads to their preservation is termed mașlahah. In contrast, mafsadah is that which harms these five essentials, so it must be prevented and eliminated." (Rysuni Ahmad, 2014: 90) Thus, the protection 


\section{Mohammad Shihan, Abdulhamid Mohamed Ali Zaroum, 470 \\ Muhammad Amanullah}

and the promotion of fundamental human rights are far more important than the blind obedience to narrow rules.

\section{Preserving the maqāṣid through protection and development}

The definition of mașlahah comprises the notion of acquisition (tahṣill) and preservation (hifz). Acquisition can be interpreted as the benefit of attainment, while preservation can be construed as removing harm or protection from destruction. (Laluddin Hayathullah, 2012) It means that acquisition depicts the notion of preserving human interests by supporting the development of human interests. The term preservation means the protection of human interests from being harmed and demolished. Hence, these two kinds of benefit should be considered when the issue of the preservation of human interest is raised. This idea is based on al-Shatibi's definition of the meaning of the maqașid which is more comprehensive and includes the element of promotion instead of protection.

Further, al-Shatibi elaborates that the Sharī'ah is not only being revealed to protect or preserve the interests of these benefits but also promotes them to realize the benefit for human life. Hence, the five necessities are not only being protected but also being promoted. Accordingly, to address this comprehensive meaning of the objectives, the term hifz in the sense of preservation is not enough; ri 'ayah in the sense of protective promotion as a more comprehensive and extensive connotation. (Maszlee Malik, 2015) Thus, Ibn 'Ashur concludes that the preservation of the five necessities is achieved first by establishing and strengthening them, and second by removing all harm that might affect them. Further, he notes that the preservation of these essentials applies to individuals as well as the whole community. (Ibn Ashur, 2006) In short, the preservation of the maqāsid contains the two aspects of protection and promotion.

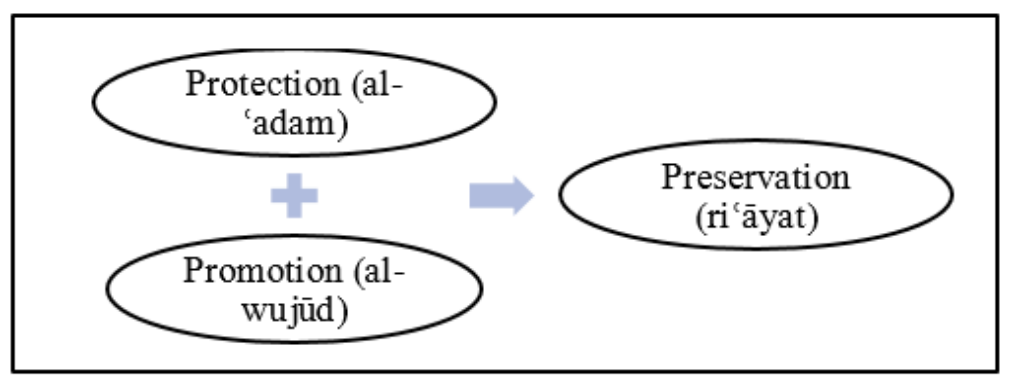




\section{Universal Maqāṣsid al-Sharī ah and Their Modern Application: To-wards Ensuring a peaceful and Secured Environment}

The above process chart shows that a comprehensive preservation of any objective is achieved by protecting it from harm on one hand and developing it by certain means on the other hand. So, each objective has two dimensions: protection and promotion. Nyazee (2003) illustrates these two 'faces' of the maqāsid by giving the example of religion. The interest of the $d \bar{i} n$ is secured by creating conditions that facilitate worship, while it is protected from destruction through jih $\bar{a} d$. Again, life is preserved by maintaining good health and protected by penalties for those who wish to destroy it. Hence, in this research the word preservation in the sense of ri 'âyah is used to depict the dual nature of the maqāșid al-Sharī'ah.

Ibrahim Ghanim (2014) points out that most of the writings on the maqāșid al-Sharī ${ }^{\complement} a h$ focus on the aspect of preservation by protection (jānib al-' 'adam) alone. The examples that are given, however, are always the same and have not been updated to this date. It seems that the scholars lacked the imagination to come up with more updated and relevant examples that reflect our circumstances today. Further, Ghanim (2014) notices that less attention is paid to the promotion and development aspect. The present condition of the Muslim ummah requires that priority be given to the part of promotion in the sense of jānib al-wujūd over the part of protection. Both aspects of the Maqāsid must be realized, and this condition is especially important for Muslim minority communities. It creates ample room for the application of Sharī $a h$ and helps facilitate their life in a nonMuslim socio-political environment. Unfortunately, most Muslim minorities tend to think with a defensive mentality which is often short-sighted, limiting, and not constructive. On the other hand, the full realization of the objectives of Islamic law opens up new means to establish their life and protect their interests in a far-sighted, open, and imaginative way. Hence, the complete realization of the maqāssid is much more beneficial to the Muslim community than just protection.

\section{The higher objectives of the maqāșid al-Sharīah and new develop- ments}

In this research the word preservation is used in the meaning of $r i$ ' $\bar{a} y a h$ to depict the dual aspect (promotion and protection) of the five universal objectives. The discussion will also cover the three levels of necessity, exigency, and enhancement, as explained earlier. This approach creates more 


\section{Mohammad Shihan, Abdulhamid Mohamed Ali Zaroum, 472 Muhammad Amanullah}

room for the application of Islamic law in a non-Muslim environment. In this context the aspect of protection (jānib al- 'adam) is hardly applicable due to its narrow and outdated perspective and its focus on criminal punishment $(h u d \bar{u} d)$ in Islamic jurisprudence. Hence, the researcher has followed the selective method to establish all five essential objectives from classic legal works and relied more heavily on the later works of modern scholars to suit the context of the Muslim minority community.

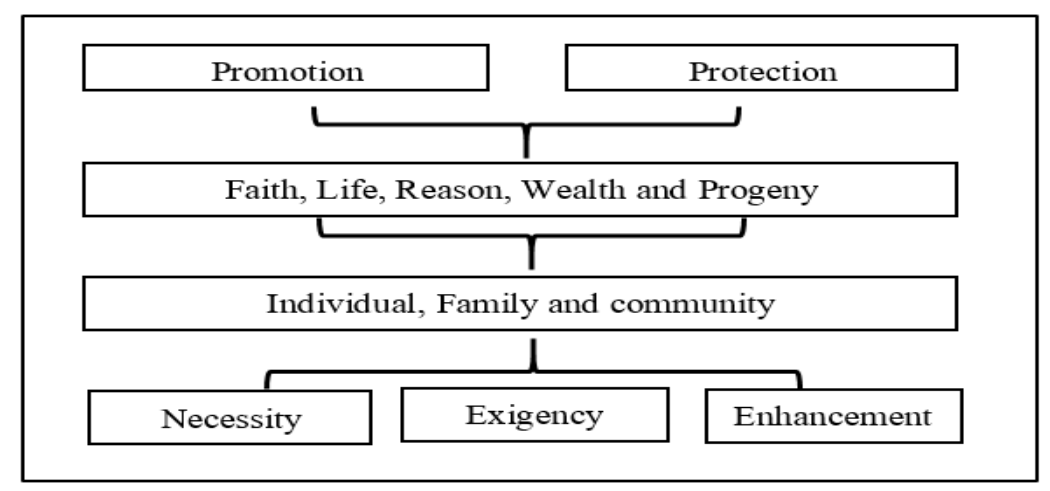

\section{Preserving life \& ensuring a peaceful and secured environment}

According to the Islamic worldview, mankind is the best of creation and the vicegerent of Allah on earth. Thus, God has bestowed high honor and dignity on all humans, regardless of their differences. (Umar Chapra, 2008) Allah said, "We have honored mankind" (Qur'an, al-Isra: 70). Further, Prophet (PBUH) declared in his last speech during his farewell pilgrimage, "Your lives, your property, and your honor are sacred as sacred on this day of yours, in this month of yours, in this city of yours." (Ibn Kathir, n.d) Thus, in Islamic Sharī ${ }^{`} a h$, the preservation of life is first considered as protecting human life from being killed or damaged based on the criminal punishment for violators as first suggested by al-Amiri. (Adil Khan Afridi, n.d )More recently, this concept was expanded by contemporary scholars when human needs had become more complex. Today the human development index has been developed to measure the conditions of human life. 


\section{Universal Maqūssid al-Sharī ah and Their Modern Application: To-wards Ensuring a peaceful and Secured Environment}

Accordingly, Islamic Sharī $a h$ has given utmost importance to preserving human life as life is considered as sacred. Furthermore, human life is granted protection in all religions. (Rysuni Ahmad, 2013) Here, the protection of human life refers to the meaning of preventing all kinds of harm to any part of the body, inside and outside, and preventing death. Further, if someone is being ill-treated by others and physically harmed, then the perpetrator is subject to the obligation of blood money or equal punishment. (Ibn Ashur, 1997) In this case, there is no difference between the life of a Muslim or a non-Muslim, an Arab or non-Arab, but regardless of all differences, human life is protected. There are explicit references in the texts of the Sharī $a h$ that urge to preserve human life, (Gamal Attia, 2007) such as "Do not take any human being's life which God has declared to be sacred, other than in the pursuit of justice." (Qur'an, al-An'ām: 151)

More importantly, the overall objective of Islamic law is to preserve the wellbeing and the order of the world. Thus, it aims to protect the interests of human beings even in a situation where there is no benefit. For example, in the case of an ignorant, poor, and senile person racked with a disease and from whom no benefit can be expected, the life of such a person is nevertheless sanctified and must be protected. Thus, the wellbeing of society and the preservation of the natural order depend on the sanctity and protection of human life under all circumstances. (Ibn Ashur, 2006)

The preservation of human life is achieved through different means. For instance, food is essential for the preservation of life. For this cause, Islamic law has taken many steps to preserve human life and ensure their health. Such as sanction like the zakat imposed on affluent people shows that it is a communal effort to eradicate poverty and preserve the lives of the poor and destitute. The two blessings enjoyed by the Quraysh were "protecting their lives and feeding their hunger." (Qur'an, alQuraysh: 4) Thus, for providing them with food and with security, Allah asked them to worship Him. This shows that sustenance and security are essential elements that ensure the survival of a community.

On the individual level, health and safety are the prerequisites for worshiping Allah. Therefore, Prophet (PBUH) said, "Whoever among you is waking up safe, feeling healthy in his body and having enough food for that day is like a person who possesses all the blessings of the world." (Sunan al Tirmizi, 2346) Ghanim (2014) connects the preservation of life with the jurisprudence of water. He develops his argument by stating that 


\section{Mohammad Shihan, Abdulhamid Mohamed Ali Zaroum, 474 Muhammad Amanullah}

water is essential for human survival. Thus, the thorough examination of the details of fiqh related to water suggests that the earlier scholars paid attention to preserving life. However, the right to use water is broader than the right to own it. Therefore, he connects the protection of life with rules and regulations developed to the fair distribution of water among people. Access to water is often the reason for conflict, so he argues that water management and equitable distribution are meant to protect human life from destruction.

Attia (2007) also discusses preservation of life from a broad perspective. He explains the adequate human diet in terms of the three levels of necessity, exigency, and enhancement. First, he says the essential diet for preserving life differs from one place to another. The essential level involves the act of refraining from prohibited food items which are harmful. At the level of exigency, it involves the availability of a variety of foods, and at the level of enhancement it involves the way food is arranged and served at the table.

Chapra (2008) suggests that the preservation of life is given preference over faith. This order is more logical in terms of sustainable development, he argues. Humans are the vicegerents of God on earth and are the ends as well as means of development. They are themselves the architects of their development or decline. In the Qur' an is stated, "God does not change the condition of people unless they change their own inner selves" (Qur'an, al-Ra'd: 11). Thus, their reform must be given utmost importance. In this connection, Aquinas urges that human's first precept is self-preservation. He establishes a series of primary precepts that are required to ensure the continuation of the species through reproduction. Further, he notes that this primary principle does not change. (Robert $\mathrm{E}$ Bowie, 2001)

In regard to this matter, Ibn 'Ashur's concerns have opened many ways for contemporary scholars to generate new views on preserving life as viewed from a broad perspective. He points out that the retribution (qișāss) is the weakest means for protecting life and does not agree with this limited classical view. He argues that the most important way of preserving life is taking precaution before something happens, such as fighting and eliminating epidemics. Ibn 'Ashur makes reference to Umar al-Khattab's refusal to enter Syria when he heard about the plague that had struck the city of Amuas in order to preserve the lives of the Muslim army. 


\section{Universal Maqūṣsid al-Sharī ah and Their Modern Application: To-wards Ensuring a peaceful and Secured Environment}

(Ibn Ashur, 2006) This opens a broad area for protecting human life beyond classical thought which is based on and limited to criminal punishment. More importantly, capital punishment is not implemented in many countries and thus a controversial subject. At this juncture, the application of the Sharíc $a h$ is a sensitive matter, especially for Muslims living in nonMuslim environments. The traditional, narrow view does not create room for the protection of life but only shows that Islamic law is not concerned with preserving human life. Hence, Ibn 'Ashur's ideas have widened the scope of Islamic law and extended its scope beyond the circle of capital punishment to safeguard human life.

At this juncture, it is worth noting the argument of Cheryl Bernard (2003) related to the failure of Islamic governance in Iran by applying Islamic law to deter crime. He said that generally, the Muslim public believes that Sharí ${ }^{-} a h$ law deters crime and that a stricter application of Islamic law will solve the social problems. However, he restricts the means of deterring crime to the application of Islamic criminal law alone which is wrong because in Islamic criminal law, qișās is the weakest means to protect human life, and it is not the only means. There are many different means to deter crimes and solve social problems. This issue also demands that a broad perspective has to be applied when looking at Islamic law, which is only possible in light of the objectives of Islamic law.

Accordingly, the above discussion on the preservation of human life shows that human life has indispensable value and dignity in the Sharī ${ }^{`} a h$ since it has sanctioned the life of everyone. Further, the Sharī $c a h$ protects the right to life for all people, regardless of their differences. A healthy and sufficient diet is necessary for the preservation of all human life. Islamic Sharī $a h$ has given the preference of water utilization over the right of possession. Moreover, the Sharī $a h$ does not limit its protection for human life to sanctioning capital punishment which is considered as a lower means for protecting life. Hence, Islamic law can ensure the preservation of human life by the necessary means.

More importantly, the preservation of human life is not limited to the individual level but extends to preserving the existence of a whole community. Ibn 'Ashur asserts that realizing these five indispensable objectives is essential for individuals and the community. The smooth func- 


\section{Mohammad Shihan, Abdulhamid Mohamed Ali Zaroum, 476 Muhammad Amanullah}

tion of the social order depends on the preservation, protection, and promotion of these essentials, suppose not, the order of the community will collapse. (Ibn Ashur, 2006) Hence, in the absence of security and safety in a community the people might face serious challenges and the smooth function of the community will be distorted. So, priority should be given to ensure security and peace to protect other fundamental human basic human rights.

The Qur'an mentions the failure to ensure the security of the people: "Did not Allah check one set of people by means of another, there would surely have been pulled monasteries, churches, synagogues and mosques in which the name of Allah is commemorated in abundant measure.” (Qur'an, Al-Hajj: 40) In this respect, Saifuddin 'Abd al-Fattah (2006) states that the Sharī $a h$ aims to ensure the survival of the Muslim community and its unique identity through the preservation of the universal objectives.

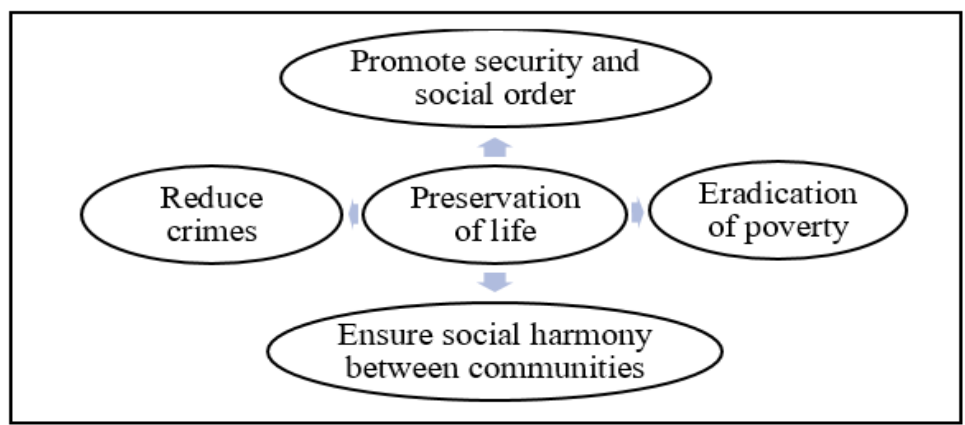

Umar's refusal to enter Syria when he heard about the plague can also be understood as his intention to control the spread of the plague to other cities. Hence, he wanted to preserve the entire humanity from that plague. (Ibn Ashur, 2006) Ibn Taymiya's time was a period of great danger and peril, and he drew certain conclusions from it. The Muslim empire faced an existential threat from invading Tatars and crusaders. Ibn Taymiya himself was punished and persecuted by the Mamluks and he died in prison. However, he defended the rule of the Mamluks and said, "If this band should perish, Islam will be lost, and so will the ummah." He under- 


\section{Universal Maqāṣid al-Sharī'ah and Their Modern Application: To-wards Ensuring a peaceful and Secured Environment}

stood that despite the Mamluk's despotism and oppression, they could defend the realm from foreign invaders. He understood that at the time the higher priority was that of preserving the ummah's very existence. (Gamal Attia, 2007: 35)

Accordingly, the preservation of life should be understood from different perspectives. Ibn 'Ashur opened the door so that contemporary scholars like Attia can extend the scope of the maqāssid and add new aspects to them. He added the aspect of the survival of the Muslim ummah and humanity, such as preserving the institutional organization of the ummah, maintaining security, establishing justice, cooperation, solidarity, enhancing mutual understanding, achieving global peace, and protecting human rights. (Gamal Attia, 2007) Eventually, all these aspects are aimed to preserve not only the Muslim ummah but all of humanity. Hence, this broad perspective is more important for a Muslim minority community who needs to collaborate with others to preserve its own interests and the interests of others equally.

\section{Preserving wealth \& environmental protection and development}

Islamic law gives much attention to the preservation of wealth, and it has set up certain principles for its acquisition and distribution. Further, it considers the acquisition of wealth by permissible means as a meaningful and praiseworthy action that is rewarded by God. However, the preservation of wealth applies to the wealth of individuals, families, and the Muslim community at large. (Gamal Attia, 2007) The Sharícah texts reveal that wealth is an indispensable need for the establishment of the Muslim ummah, such as the Qur'anic verse," Who believe in the unseen, are steadfast in prayer, and spend out of what We have provided for them" (Qur' an, alBaqarah: 3) and "O you believer! Spend out of the bounties We have provided for you." (Qur'an, al-Baqarah: 254) and "And when the prayer is finished, then you may disperse through the land and seek of the bounty of Allah." (Qur'an, al-JumÑah: 10) and "Go forth, (whether equipped) lightly or heavily, and strive and struggle, with your goods and your persons, in the cause of Allah. That is best for you if you (but) know" (Qur'an, alTawbah: 41).

Selamah Abdullah Yusuf (2008) defines wealth or capital (māl) as all the resources Allah has made subservient to His vicegerents and can be defined as anything that can be owned and has value, including the rights 
Mohammad Shihan, Abdulhamid Mohamed Ali Zaroum, 478

Muhammad Amanullah

and benefits of ownership. Further, he denotes that ownership of rights for human beings is based on the concept of khiläfah, where Allah is the sole owner of wealth and human beings are trustees and custodians.

In the classical view of the preservation of wealth, al-Juwayni and al-Gazali illustrate the protection of wealth from theft by cutting off the hands of thieves. Al-Shatibi views the preservation of wealth as the prohibition against injustice, depriving orphans of their inheritance, wastefulness, envy, giving short measure and weight, and causing corruption in the world. According to Ibn Ashur, who extended the scope of the maqāssid to include the individual, family, and community level, the preservation of wealth means the protection of the wealth of the ummah from being abandoned and from falling into the hands of others without compensation. Further, he developed five objectives of the Sharī'ah related to the economy, which are marketability, transparency, preservation, durability, and equity. (Ibn Ashur, 1997) In this respect, he points out that preserving individual wealth also means, in extension, preserving the community's wealth. Thus, preserving all is achieved by preserving its constituent parts. (Ibn Ashur, 2006) This aspect is of special importance in the Muslim minority context where conflicts with the majority community may lead to the intentional destruction of the economic resources owned by the minority.

Furthermore, Najjar has developed his own approach to the issue of wealth which is thought-provoking and highly appreciated in the current academic and political discourse on sustainable development. He discusses the preservation of the universal environment as part of the objectives of the Shari ${ }^{-} a h$ and identifies two objectives: the preservation of wealth and the preservation of the environment. In respect to the latter objective, he calls upon the Muslims to protect the environment from destruction and pollution. (Najjar, 2008) Presently, climate and environmental crises have earned the close attention of global leaders, and the Muslim countries are not immune to these threats. His practical take on the subject is adoptable by the Muslim minority community who can actively contribute by supporting and participating in national projects related to environmental issues.

In this respect, Allal Fasi's definition of the maqāșid al-Sharī ${ }^{`} a h$ includes the development of the earth's resources ( 'imārat al-ard) as an objective that indicates the role of wealth and the importance of preserving 


\section{Universal Maqūssid al-Sharī ah and Their Modern Application: To-wards Ensuring a peaceful and Secured Environment}

it. (Allal al-Fasi, 1973) Chapra (2008) makes a significant observation on the preservation of wealth. Even though al-Gazali and al-Shatibi placed the preservation of wealth at the lower end of their hierarchy, he argues that it does not necessarily mean that it is less important than all other essentials. It is important for the other four primary objectives as well because without it they may not be enhanced to ensure general wellbeing.

Yusuf identifies the duality aspect of the preservation of wealth objective in the form of protection and development. Hence, he notes

The preservation and the protection of wealth can be taken as the protection (jänib al- 'adam) of ownership and property from damage, harm, theft, exploitation, or injustice. Also, it encompasses the acquisition and development (jānib al-wujūd) of wealth by making it available through circulation and equitable distribution and opportunities for development, as well as preserving the wealth through investments and good governance.' (Selamah A Yusuf, 2018: 185-203)

It is worth noting here that the preservation of wealth can be achieved through five dimensions: preservation of wealth through acquisition and development, protection of ownership, protection from damage, circulation, and through its circulation protection of value. (Dasuki and Said, 2011) According to Chapra, wealth protection is fulfilled with the availability of wealth as necessity fulfillment, circulation of wealth as a form of exigency fulfillment, and enhancement fulfillment by the investment of the wealth. (Meri Indri Hapsari and Sri Herianingrum, 2018) Meri Indri (2018) notes that the variables of the preservation of wealth are property ownership, property growth, and property distribution.

Notably, the importance of this objective as viewed by Chapra and Yusuf is also applicable in the Muslim minority context. Their perspectives give a clear and comprehensive picture for a minority community to be self-sufficient in their economy and preserve their wealth for the comprehensive wellbeing of the whole community. The Muslim community's wealth and properties in Sri Lanka are purposefully targeted and destroyed to weaken their economic status and marginalize them. This situation means that they need to find legitimate ways to protect and preserve their capital, which might be discussed profoundly in another article. 
Mohammad Shihan, Abdulhamid Mohamed Ali Zaroum, 480

Muhammad Amanullah

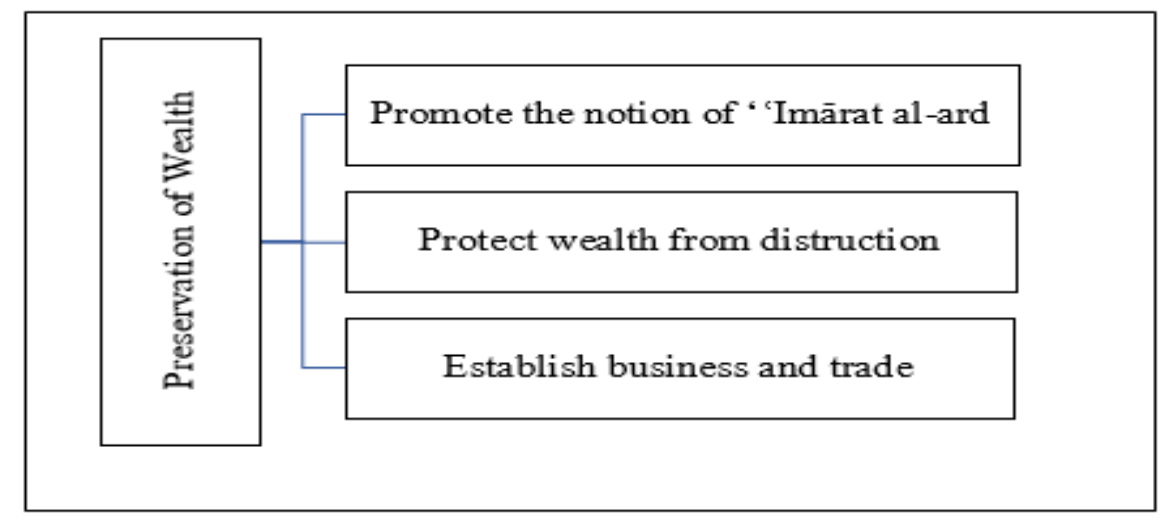

\section{Thinking beyond the five essential objectives}

The issue of extending the scope of the maqāșid is part of the current academic discourse among contemporary scholars since it paves the way for a more comprehensive perspective of the Shari ${ }^{\top} a h$ and its application today. The discussion centers on the idea that the classic essential objectives are limited to the individual level and do not consider the change of time and place and new developments. However, the need to expand these essential objectives is acknowledged because they law has to address the changes in modern society. Islamic law cannot be limited to the individual sphere since new social, economic, political, and educational circumstances and related issues require new developments in this area. This shift has been initiated by Ibn Ashur, as explained by his commentator Ismail al-Hasani:

Identifying essential human interests in society is subject to what is dynamic in society and not to what is static, to what is variable and changing and not to what is constant and unchanging. In other words, the determination of the essential in Islamic society is based on a comprehensive understanding of and full attention to recent and unexpected developments and changes in Islamic society and the broad human society in general. This means that it is not enough to depend on the declaration of the law when establishing the basis for essential interests. Still, they must pay attention to the changing circumstances in which such declarations are made. This understanding calls for recognizing the historically determined nature of the decision to restrict human beings' essential interests to nothing but preserving religion, life, intellect, progeny, and wealth. 


\section{Universal Maqūssid al-Sharī ah and Their Modern Application: To-wards Ensuring a peaceful and Secured Environment}

Furthermore, this calls to include other interests that Islamic society need to preserve more at the current time: the right to free expression, freedom of political association, the right to elect and change the rulers, the right to employment, sufficient food, housing, and clothing, the right to medical care are aptly considered as essential to human existence in modern society.' (Gamal Attia, 2007:68)

The argument for the expansion beyond the five essential relies is due to several factors. One such factor is that these five necessities established by the earlier scholars hardly address communal matters and are limited to the individual realm. In this respect al-Qaradawi writes:

I accept as true that the Maqāșid those which have to do with society at large has not been given its due. Most of the Maqāșid is related to the individual rather than the community, such as protecting an individual's religion, faculty of reason, life, wealth, and progeny. Then, where are freedom, equality, justice, and of what value are they? This, too, urges for review and reassessment. (Gamal Attia, 2007: 84)

Yasir Ibrahim (2014) asserts that "the modern application of the classical model has been unable to produce significant practical results without expanding the number and scope of what is considered necessary Maqāșid."

Nejatullah Siddiqi (2016) generates his arguments in favor of the further development of the maqāșid to address modern social, economic, political, environmental, health, and technological issues and challenges. He rejects the argument of some scholars that the five universal essentials include all other matters within, and that there is no need of additional objectives or a reform of the exiting objectives. For example, the objective to preserve life logically includes the objective to eradicate poverty and enhance social cooperation. This view is acceptable in principle but we need to expand the objectives and produce new terms that have never been formulated in traditional fiqh to meet the requirements of modern developments and changes in the present world order.

It is worth noting the argument of Chapra on the need to expand the scope of the maqāsid. He explains that the primary purpose of Islamic law is to promote the wellbeing of all of humanity, irrespective of race, 


\section{Mohammad Shihan, Abdulhamid Mohamed Ali Zaroum, 482}

Muhammad Amanullah

religion, age, sex, or nationality. He reminds of al-Gazali's words:" The very objective of the Sharī $a h$ is to promote the wellbeing of the people which lies in their preservation of five necessities namely faith, self, reason, progeny and wealth." (Umar Chapra, 2008: 34) Chapra (2008) argues that these five primary objectives are no longer enough to ensure the wellbeing of humanity. Still, scholars indicate other corollaries from the texts of Sharí ${ }^{c} a h$ that are vital and indispensable because the realization of the primary objectives is impossible without the corollary objectives.

As mentioned above, the argument of expansion of essential objectives began with Ibn Ashur who introduced new objectives and thus widened the scope of the maqāssid al-Sharī ${ }^{\complement} a h$. Since then, contemporary scholars have added and expanded his system considering the new developments and new social, political and economic orders. Anas 'Ali notes, "Ibn Ashur introduced new modern terminology to the realm of maqāșid that were never formulated in traditional theory. For example, he develops the theory of 'preservation of lineage' into 'preservation of family system' and 'protection of faith' into 'freedom of beliefs."'

Moreover, Ibn Ashur (2006) introduced the notions of orderliness, civility, freedom, equality, natural disposition, and rights as new objectives. In this connection, el-Mesawi stresses that Ibn Ashur's contribution to the maqāsid discourse was "a well-thought-out response to the philosophical and socio-cultural challenges posed to the Muslim Ummah by modern Western civilization with its dominant secular worldview." (Tahir al-Mesawi, 2018) Furthermore, al-Fasi expanded the scope by adding notions such as the establishment of justice and equality, preservation of freedom of thinking, and ensuring security and quietness. (Allal al-Fasi, 1973)

In the expansion process of the maqāșid al-Sharī ${ }^{\top} a h$, the contribution of Attia must not be understated. His new conceptualization 'from the five universals to four realms' enables the Muslim minority community in particular to accommodate them, broaden their minds, and open new ways to facilitate them. He divides the five universals into the four realms of individual, family, community, and humanity. Hence, the objectives he sets for community and humanity are more suited to circumstances experienced by Muslim minority communities. In the realm of the Muslim community, notions such as the institutional organization of the ummah, the establishment of justice, preservation of morals, cooperation, solidarity, and responsibility, and dissemination of knowledge are pivotal and 


\section{Universal Maqāṣsid al-Sharī ah and Their Modern Application: To-wards Ensuring a peaceful and Secured Environment}

should be paid closer attention. In the realm of humanity, he introduces new objectives such as mutual understanding, cooperation and integration, realizing human stewardship of the earth, creating a new world order based on justice, global protection of human rights, and dissemination of the message of Islam are indispensable for a Muslim minority community to survive and be a witness for Islam. (Gamal Attia, 2007)

Siddiqi (2016) also agrees to add new objectives to the five universal objectives such as justice and equality, honor and dignity of humanity, basic freedom, eradication of poverty and sustenance for all, bridging the gap between rich and poor, and social justice equality, global peace, preservation of system and order. Muhammad al-Gazali proposes to add justice and freedom to the five essential objectives stating that the corrupt rule of Muslim ummah over the centuries has caused much damage and baneful outcomes. (Gamal Attia, 2007) Further, he cited the Qur'anic verse, "Indeed, (even aforetime) did we send forth Our apostles with all evidence of this truth; and through them We bestowed revelation from on high, and thus gave you a balance (where with to weight right and wrong), so that men might behave with equity." (Qur'an, al-Hadīd: 25)

Hence, the expansion of the maqāșid beyond the five necessities is vital for realizing the wellbeing of humanity which is the ultimate objective of the Sharī'ah. For example, take the view of Najjar on the protection of wealth; he does not limit its objective to the wealth that people can earn and extends it to the development of available resources and the protection of the environment. His view is thought-provoking and highly appreciated in the present context where sustainable development goals (SDG) have become the main subject of public discourse. Thus, he presents the preservation of the universal environment as another objective of the Sharī ${ }^{-} a h$ and differentiates between preserving wealth and preserving the environment. (Abdul Majid Najjar, 2008) This is especially noteworthy at present with the current global attention on the climate and environmental crisis. Also, his approach suits the present context better and proves the timelessness of the Sharī $a h$.

At this juncture, the criticism of Ghanim on the stagnation of Islamic jurisprudence generally and the maqāsid al-Sharī'ah particularly is interesting and thought-provoking. He observes that in Islamic jurisprudence, the scholars have been citing the same examples for many centuries. 


\section{Mohammad Shihan, Abdulhamid Mohamed Ali Zaroum, 484 \\ Muhammad Amanullah}

As a result, even the contemporary scholars have failed to produce new examples to reflect the current circumstances. The same criticism applies to the maqāssid scholars who insist on repeating the same age-old examples and thus appear to be stuck in the past. (Ibrahim Ghanim, 2014) Such a passive approach does not pave the way for the reform and extension of the scope of the maqāssid and only widens the gap between Islamic law and the modern world, especially in terms of regulating social and communal life. According to Ghanim, (2014) this lack of imagination on part of the scholars and their lack of engagement with the real world and its present problems are the reason for their redundancy and increasing irrelevancy in the global intellectual discourse.

Besides, Anis Ahmad (2020) makes the important point that the universal principles of Islamic law such as justice, equality, leniency, freedom, and security can be applied by all people, regardless of their religious background. Thus, it is not necessary to propagate them under the exclusive theme of 'Islamic Sharī'ah' since Islamic law is based on tawhìd and is meant as a blessing for all of humanity. He hopes that whoever wants to benefit from these Islamic legal principles should do so, without hesitancy and without second thoughts. Indeed, this broad perspective of the Sharī ${ }^{\prime} a h$ can assist the Muslim minority community to accommodate itself peacefully in a non-Muslim environment and opens new venues of collaboration. Thus, the application of Islamic law can be seen approached from two viewpoints: the Sharī $a h$ guidelines are only related to the Muslim community or the universal values and principles relate to all of humanity. The observation noted by Rashid al-Ghannushi (1998) is more applicable to our context. He states that "a just government, even if not Islamic, is considered very close to the Islamic one. Because justice is the most important feature of an Islamic government, it is said that justice is God's law."

Consequently, the expansion of the scope of the maqașid beyond the five universal objectives paves the way for new thinking and broadens the views Muslims have on the nature and purpose of the Sharī $a h$. Thus, this expansion is imperative for a Muslim minority community that wishes to be accommodated in a non-Muslim society and wishes to collaborate with other religious communities to achieve common aims. Thus, objectives such as establishing justice, freedom, and equality, eradicating poverty, enhancing education, and preserving the environment are vital for this purpose. 


\section{Universal Maqūssid al-Sharī'ah and Their Modern Application: To-wards Ensuring a peaceful and Secured Environment}

\section{The role of the maqāșid al-Sharīah today}

Indeed, in the history of Islamic legal theory and its development, the notion of the primary objectives of Islamic law remains a crucial aspect of legal study. It has finally caught the attention of an increasing number of modern Sharīah scholars. Legal scholars have always used the maqāssid theory to elucidate the wisdom behind the rulings of the Shari' $a h$ and employed it to extend the law to new circumstances and assist in judging cases of apparent conflict between certain rulings. Today, the maqāssid theory is a popular trend in Islamic legal theory. Contemporary scholars view it as a valid method of interpreting the revealed text and as a valuable instrument for solving contemporary issues because it helps reform Islamic thought and civilization.

Imam al-Shatibi (d.790AH) dubbed as the father of the maqāșid alShari ${ }^{-} a h$ has described the qualifications for a mujtahid. First, the mujtahid must have a solid understanding of the objectives of the Sharī $a h$. Second, he must be able to generate a ruling based on his or her understanding of the objectives of the Sharī'ah. (Shatibi, n.d) Centuries earlier Imam al-Juwayni, (d.478/1085), the first teacher of the maqāssid according to Rysuni, (2013) had highlighted the importance of understanding the objectives of the law: "Our foremost attention goes to denote to their end goals and objectives because the person who fails to comprehend the end goals from our practices might dismiss the understanding of the totality of the Islamic Sharīah." (Al-Juwaini, n.d) Further, his disciple al-Gazali said, "For a $m u$ jtahid, he must have a thorough grasp of the higher objectives of the Shari ${ }^{-} a h$ and be skilled in raising and reflecting on relevant questions and issues and ordering them in terms of their relative degrees of importance." (Shabbar Said, 2018: 10) Therefore, earlier scholars wrote, "When a person comprehends the objective of something, then the way for its achievement becomes easy for him. For example, a person who does not understand the objective of $z a k \bar{a} t$ then becomes stingy and tries to find ways for the evasion of it and to fraud to drop it. On the contrary, who comprehends the objectives and benefits of zakät is unlike the former, and he pay it with full of satisfaction." (Rysuni Ahmad, 2014: 128)

Thus, it is vital to understand the role of the maquassid al-Sharī $a h$ and how it can be applied to revive Islam today. First, the Qur' an and the Sunnah are the fundamental sources of Islamic legal theory. Hence, any 


\section{Mohammad Shihan, Abdulhamid Mohamed Ali Zaroum, 486 \\ Muhammad Amanullah}

science, fundamental, principle, or method can only be derived from these two sources. Allah stresses this in the verse, "Nothing has we omitted in the Book" (Qur'an, al-An 'ām: 38). In other words, the Qur' an and the Prophetic traditions are the fundamental sources of Islamic legal theory. At this juncture, it is vital to elaborate on how the objectives or principles of the Sharī ${ }^{c} a h$ can be derived from the textual sources. Indeed, the limited texts of the Sharī $a h$ cannot address all the problems of humanity. On the other hand, the Sharī'ah is universal and eternal; it provides general principles and rules and has opened the door to independent reasoning to develop solutions for all the different problems, in all locations and in all times.

In this connection, it is worth mentioning here that the maqāșid alSharī'ah do not only reflect the objectives of Islamic law. Its scope can be expanded and used a tool to formulate the fundamental principles and cardinal values related to human welfare in line with the descending order of human needs. Further, it helps articulate the systematic understanding of Islamic teachings. (El Mesawi, 2009) Further, 'Umar Chapra notes that "any interpretation or verdict which is not in harmony with the objectives of Shari ${ }^{c} a h$ and is likely to lead outcomes that may hurt human wellbeing, need to be reconsidered carefully either adjusted or rejected outright." (Umar Chapra, 2008: 28)

Accordingly, Akhtarzaiti (2018) noted that the Maqāșid alSharī ${ }^{\prime} a h$ as an independent discipline is part of the philosophy of Islamic law governing the legal rules and reflecting the Islamic worldview in general. It is important to note here that the Maqūșid al-Sharī ${ }^{`} a h$ represent a goal-oriented approach to lawmaking. Therefore, Marybeth says, "Muslim legalists could reconcile the rigid madh ' $h a b$ formulas of Ușül al-Fiqh with the complementary principles of Maqūssid al-Sharī'ah." Besides, "rather than only relying on analogical legal theory, scholars like al-Ghazali, alShatibi, and Ibn 'Ashur projected to shift toward goal-oriented lawmaking that permits for more elasticity and adaptation in a dynamic and everchanging world." (Acac Merybeth, 2015: 59-78)

Al-Qaradhawi clarifies that the ultimate role of the maqāșid al-Sharī $a h$ is to arrive at a proper understanding of the Sharī $a h$. He writes:

If one takes a text of Shari 'ah, Qur'an, or Sunnah, without knowing other hadith or to the practice of Prophet (PBUH) and without relating it to the objectives of the $\operatorname{Sharī}^{\mathrm{c}} a h$, then, it is possible to 


\section{Universal Maqāṣsid al-Sharī ah and Their Modern Application: To-wards Ensuring a peaceful and Secured Environment}

misunderstand and misinterpret the Sharī $a h$. Therefore, insist of Imam al-Shatibi is worth to be noted here that the comprehension of the end goals of Shari ${ }^{\complement} a h$ is a vital prerequisite for understanding the Sharī'ah. This is possible for those who are knowledgeable about the verses of the Quran and the traditions of the Prophet (PBUH); why, how, and when they were revealed and the reason behind the revelation which Prophetic traditions are eternal, and which are temporal. (Yusuf al- Qaradawi, 1981: 152)

As demonstrated in the following diagram, Shaykh Yusuf alQaradawi has proposed new dimensions of Maqasid Al-Sharai'ah to accommodate new areas and not to be restricted to five commonly used by all scholars. Emphasis, according to him should be given, in our contemporary world, to the preservation and protection of some basic principles namely; respect and affection toward Al-Bi'ah (the environment), the principle of justice (Al-Adalah), the principle of responsibility ( Al-Masuliyyah), the principle of simplicity (Al-Basatah), (Ahmad Sarip, 2021) 
Mohammad Shihan, Abdulhamid Mohamed Ali Zaroum, 488 Muhammad Amanullah

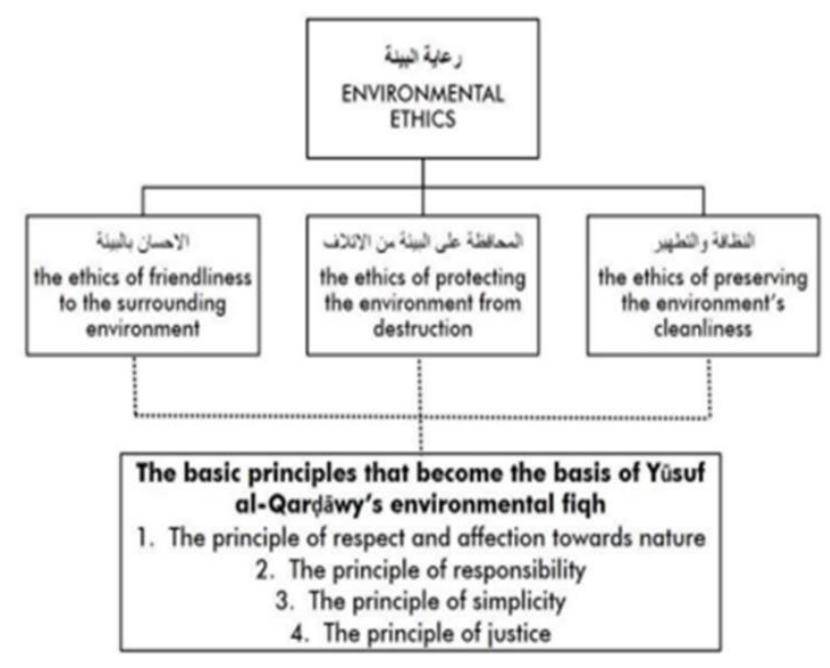

Hifdhu al-Bi'ah as Part of Maqãșid al-Sharī‘ah

\begin{abstract}
In his Ri 'âyah al-Bi'ah fi Sharä'ah al-Islâm book, Yûsuf al-Qarḍ̂wy mentions that descent condition of the living environment determines the realization of natural balance. Humans have to adopt religious principles to decide their behaviors toward nature so that its continuity and availability are appropriately preserved. Hifdh al-bi'ah (protecting environment) is equally essential as keeping kulliyat al-khamas (five fundamentals to be accomplished, namely protecting religion, soul, descendant, mind, and wealth). The terms used by Yusuf al-Qardhawi include: a) hifdh albi' ah min al-muhäfadhah 'ala al-din (preserving the environment is part of protecting the religion), b) hifdh al-bi'ah
\end{abstract}

In the same way, Raysuni (2003) elaborates the role of the maqāșid alSharī'ah as "maqāșid in terms of its principles and objectives, fundamentals and particulars, its types and strategies, its approaches and means constitutes a distinguishing methodology of thinking and viewing, analyzing and evaluating, reasoning and constructing." Furthermore, al-Qaradawi explains the way of achieving the objective of the Sharī $a h$ :

First, we need to investigate and analyze our cultural heritage in Fiqh literature with its different schools and at different ages, to choose what will ensure the enforcement of the Maqāssid and the resurrection of al-mașlahah in light of the changes taking place in contemporary life. Second, we need to go back to our roots: i.e., to the Qur' an and the Sunnah, to analyze it in light of the Maqāșid. Third, we need to make a great effort to understand contemporary issues that were not part of our ancestors' life, i.e., where the old Fuqaha $\bar{a}^{\prime}$ did not contribute to the issue as it relates to our modern time. ( Qaradawi, 1973: 108-109) 


\section{Universal Maqūssid al-Sharī ah and Their Modern Application: To-wards Ensuring a peaceful and Secured Environment}

In this connection, el-Mesawi (2007) exposes the evaluative and corrective's role of the maqāșid al-Sharī'ah. He explains that classic and contemporary Muslim scholars have used these methodological approaches in interpreting and explaining the texts of the Sharī $a h$. Furthermore, the maqāșid al-Sharī'ah can be used not only as a tool for reviewing and correcting previous interpretations and understandings but also suspending meanings that unequivocal textual statements of the Sharī $a h$ have expressed. Hence, it helps formulate the principles, values, and commands of the Sharī ${ }^{\prime} a h$ in such a systematic way.

According to Attia, (2007) objective-based ijtihād plays a vital role in generating solutions for emerging new issues by establishing three distinct dimensions. The first dimension is built by expanding the scope of analogy ( $q i y \bar{a} s$ ), the second by deriving the benefits and aversion of harm based on the texts, and the third dimension through the notion of unrestricted interests. (Tahir al-Mesawi, 2018) In this connection, Kumara Adji Kusuma (2018) describes its essence as "the objectives of the Sharī'ah and the rationale of the Sharī ${ }^{-} a h$. It is a comprehensive and careful examination of Sharī ${ }^{c} a h$ rulings that entails the understanding that the Shari ${ }^{c} a h$ aims to protect the interests of the people in all aspects of life." Furthermore, he asserts that every Shari ${ }^{\top} a h$ ruling comes with a purpose and that the texts clearly state the reasoning behind the rulings. (Kumara Adji, 2018)

Furthermore, Sherman A. Jackson notes that the maqāșid approach is an alternative approach to interpreting and understanding the texts. In this approach the substance and authenticity of the text are not enough to measure its weight, but on its relationship to universal meanings and values that are inductively extrapolated from an aggregate of texts. Hence, legal matters are to be resolved by referencing inductively established values and principles, even in the absence of explicit texts. (Tahir al-Mesawi, 2018)

In addition, Abu Suleiman (2011) explains that adopting an objective-based approach to finding solutions for new developments and circumstances where there is no explicit text is absolutely necessary. Further, one of the main reasons for prevailing difficulty in deriving a valid analogy between a new circumstance and a text that applied originally to an earlier condition is the lack of understanding about the differences of time and place in both situations. Accordingly, it is impossible to find a genuine 
Mohammad Shihan, Abdulhamid Mohamed Ali Zaroum, 490

Muhammad Amanullah

contradiction between the text of revelation and the realities of existence. But there is a possibility of inappropriate understanding of either revelation or the realities of existence. Therefore, priority must be given to universal and higher objectives until the source of the misunderstanding has been identified to avoid harming the people and their welfare.

Equally, al-Alwani stresses the importance of the objective-based approach. He argues that it is a comprehensive, holistic, and universal method for finding solutions to the ever-increasing problems of humanity. He warns that abandoning this approach in Islamic legal study will lead to the misinterpretation of the Sharí ${ }^{c} a h$ texts. He labels this objective-based approach as a crucial tool for understanding the revelation. (Maszlee Malik, 2015) In this respect Anas 'Ali noted that the knowledge of the maqus șid is a prerequisite for any attempt to address and resolve contemporary issues that deal with Islamic thought. Moreover, such knowledge can help in the process of developing a new and much-needed objectivebased fiqh for minorities. (Gamal Attia, 2008)

\section{Conclusion}

This article has discussed the universal maqāșid al-Sharī ${ }^{\circ} a h$ as reflected in the major works of contemporary scholars. It has been noted that the new developments require new approaches and the use of new terminology to meet present-day circumstances and challenges. Furthermore, the researcher has emphasized the role of the five universal objectives to address the Muslim minority context. The researcher has examined the recent proposals to expand the objectives beyond the five essentials to meet the present requirements and needs. It has been found that this expansion is imperative for all Muslims all over the globe especially the Muslim minority communities

It has further been shown how new objectives such as justice, equality, leniency, freedom, security and the protection of the environment are more appropriate in the Muslim minority context as they allow the Muslims to create a common platform to collaborate with other communities in a peaceful manner. These objectives can be applied by non-Muslims as well and do not need to be treated as the exclusive property of Islamic law. Perhaps, in the near future, the researchers might embark on some 


\section{Universal Maqāṣid al-Sharī' ah and Their Modern Application: To-wards Ensuring a peaceful and Secured Environment}

studies to explore important notions related to the maqāșid al-Sharī'ah that shape the legal approach to deriving rulings for new issues and challenges.

\section{References}

Abdul Fattah, Saifuddin. (2006). Activating MaqÉsid paradigm in Political and Social Fields. in Studies in the Philosophy of Islamic Law: Theories and Applications. Ed, Mohamed S. El-Awa. Al-Furqan Islamic Heritage Foundation. London.

Abu Suleiman, Abdul Hamid. (2011). The Quranic worldview a springboard for cultural reform. International Institute of Islamic Thought. London. Washington.

Acac, Marybeth. PANCASILA A contemporary Application of MaqÉsid al-SharÊẼah. Journal Indonesian Islam. Vol, 09, No-01. June. 2015

Adil Khan Afridi, Maqasid Al Shariah and preservation of basic right, Journal Education and Social Science, Vol.4 (June)

Akhtarzaite Binti Abdul Aziz (2018). DharÉ'iÑ and MaqÉsid alSharỄNah. A study of aspects of Islamic law in MaqÉsid alSharÊÑah; explorations and implications. Ed; Mohamed El-Tahir el-Mesawi. Islamic Book Trust. Kuala Lumpur. pp- 347-373.

Amiri, Abu al Hasan. (1967). 'al I'ÑlÉm bi manÉkib al Islam'. Ed by Ahmad Abd alHamid. DÉr al KitÉb al Arabi. $1^{\text {st }}$ ed.

Anis Ahmad, Crisis in the Muslim Mind Revisited, Zoom Meeting with IIIT students of IIUM, 21, 04 2020, 20.00pm - 21.10pm.

Attia, Gamal. (2007). Towards realization of the higher objectives of Islamic law, London. International Institute of Islamic Thought.

Bernard, Cheryl. (2003). Civil Democratic Islam; Partners, Resources and strategies. RAND Corporation. (National Security Research Division). Arlington. 
Mohammad Shihan, Abdulhamid Mohamed Ali Zaroum, 492

Muhammad Amanullah

Dusuki, Asharf \& Said Bouheraoua. (2011). 'The framework of MaqÉsid al SharÊN $\tilde{N}$ h and its implication for Islamic Finance'. ISRA Research paper. No. 22/2011.

FÉsi. AllÉl, (1973). MaqÉsid al-SharÊÑah al-Islamiyyah wa MakÉrimuha. Al-DÉr al-Baidha.

Ghanuushi, al-Rashid. (1998). 'Participation in non-Islamic government'. in Charles Kurzman. ed. Liberal Islam. A source Book. Oxford. 1998. p- 94.

GhÉnim, IbrÉhim al-Buyumi. (2014). Maqsad hifz al-Nafs fi fiqh almiyÉh. (The purpose of self-preservation in the Jurisprudence of water). Al-Furqan Islamic Heritage Foundation. London.

Gazali, Abu Hamid, (1997) al-Mustafa fi Ilm al-Usul, (ed) Muhammad Suleman al- Ashqar, Beirut, Muassassat al-Risalah.

Ibn ÑÓshËr, Muhammad TÉhir. (1997). MaqÉsid al-SharỄ̃ah al-IslamiyyÉh (Higher Objectives of Islamic Law) ed. Muhammad El-TÉhir El-MesÉwi. Malaysia: Al-BasÉir.

Ibn Ashur, Muhammad TÉhir. (2006). "Ibn Ashur Treatise on MaqÉsid al-SharÊENah" (Translated from Arabic by Muhammad al-Tahir elMesawi) International Institute of Islamic Thought, London.

Ibrahim, Yasir S. (2014). An Examination of the Modern Discourse on Maqasid al- Sharia. Journal of Middle East and Africa.

JuwaynÊ, Abd al-Malik. (1997) Al-Burhan Fi Usul al Fiqh (The Proof in the Fundamentals of Law), $4^{\text {th }}$ ed. (Al-Mansurah, Egypt: al wafa).

Juwayni, Abu al-Ma'Éli, Al Burhan (Evidence in the origins of the law), Qatar, n.d.

Kumara, Adji Kusuma. (2018). Zakath Index: Welfare Measurement under the MaqÉsid al- Shariah' in MaqÉsid al-Shariah based index of Socio-Economic Development. IIUM press, Gombak. 
493 Universal Maqāṣid al-Sharī ${ }^{\prime} a h$ and Their Modern Application: To-wards Ensuring a peaceful and Secured Environment

Laluddin, Hayatullah, (group of authours). (2012). An analysis of Maslaha's Development Through al-Gazali pre and post al-Gazali Periods. International Business Management. 6 (2): 187-193.

MaqÉsid al-SharÊÑah explorations and implications. (2018). Ed. Tahir alMesawi.Islamic Book Trust. Selangor. Malaysia.

Maszlee Malik. (2015). Presented paper at the forum on 'MaqÉsid Shariah in a constitutional Democracy'. 31, oct at Penang, Malaysia.

Meri Indri Hapsari \& Sri Herianingrum (2018), Construction of MaqÉsid al-Sharaih index for Socio Economic Development, in MaqÉsid alShariah based index of Socio-Economic Development, IIUM press, Gombak,

Mesawi. El-TÉhir. (2009). MaqÉsid al-SharÊÑah. Encyclopedia of Islamic Economics. Vol-1. Principles, Definitions and Methodology. Ed. Nejathullah Siddiqi. London.

Mesawi, el-Tahir (2018). 'MaqÉsid al-Shariah exploration and implications. Islamic Book Trust. Selengore.

Najjar, Abd al Majid. (2008). MaqÉsid al Sharaih Bi Abad Jadidah. Dar al garb alIslami.

Nejathullah Siddiqi, MaqÉsid al-Shariah wa al-Hayath al-MuÉsirah, (Trans by- Mohammad Rahmathullah) Dar al-Kalam, Dimashq, 2016

Nayzee, Imran Khan. Islamic Jurisprudence. (Usul al-Fiqh). The International Institute of Islamic Thought. The other Press. Kuala Lumpur.

Qaradawi, Yusuf. (1973). Shariat al-Islam: Khuluduha wa Salahuha li alTatbiq fi Kul Zaman wa Makan (Islamic SharÊÑah: its Applicability Regardless of Time and Place). AL-Maktab al-Islami. Beirut.

Rejeb Senturk. 2013. Human rights in Islamic Jurisprudence. in 'The future of Religious Freedom Global Challenges'. ed- Allen D. Hertzke. Oxford University Press. pp- 290-311. 
Robert E Bowie. (2001). Ethical Studies. Nelson Thornes Ltd. United Kingdom.

Rysuni, Ahmad. (2003). Al-Fikr al-MaqÉsidi. Dar al-Huda. Beirut.

Rysuni, Ahmad. (2013). MuhÉdarÉt fÊ MaqÉsid al-SharÊÑah. $2^{\text {nd }}$ ed. DÉr al-Kalemah.Cairo.

Rysuni, Ahmad. (2014). MaqÉsid al-MaqÉsid al-GhÉyÉt al-ÑIlmiyyah wa al-ÑAmaliyyah li MaqÉsid al-ShariÑyyah. $1^{\text {st }}$ ed. DÉr al-Kalemah. Cairo.

Rysuni, Ahmad. (2013). Al Kulliyyath al Asasiyyah li al SharÊÑah al Islamiyyah' $1^{\text {st }}$ ed.DÉr al-Kalemah. Cairo.

Shabbar, Said (2018). Ijtihad and Renewal. IIIT books in brief series. International Institute of Islamic Thought. Herndon. USA.

ShÉtibÊ, Abu IshÉq. al-MuwÉfaqÉt fê UsËl al-SharÊÑah, (ed. Abd Allah al-DarrÉz). DÉral-Kutub al-Ñilmiyyah, (n.d). Beirut. Lebanon.

Sheikh Anas Ali, 'forward' to Jamal al-Din Attia, Towards the realization of higher intents of Islamic law, Noncy Robert, p-ix.

Selamah Abdullah Yusuf, measuring wealth development based on MaqÉsid al Shariah: Hifz al Maal index, in 'MaqÉsid al SharÊÑah based index for socio economic development' IIUM press, 2018

Siddeqi, Mohammad Nejathullah. (2016). 'MaqÉsid al-SharỄNah fi alHayÉt al MuÑÉsirah' (Higher objectives of SharÊÑah in modern life). Trans; Mohammad al-Nadwi. Dar al-Kalam. Dimishq.

Umar Chapra. (2008). The Islamic vision of development in the light of MaqÉsid alSharÊÑah. International Institute of Islamic Thought. London. 
495 Universal Maqāṣid al-Sharī'ah and Their Modern Application: To-wards Ensuring a peaceful and Secured Environment

Yasir S. Ibrahim, An Examination on the modern discourse on MaqÉsid al-SharÊENah, Journal of Middle east and Africa, Vol. 5, 2014, 3960. (Add to bib)

Zuhri, Saifuddin. (2019). The confusion about Maslaha Implementation in Ijtihad Discourse. Social Science and Humanities. 27 (3): 19831902. 